Global Conferences Series:

Social Sciences, Education and Humanities (GCSSSEH), Volume 3, 2019

The $1^{\text {st }}$ International Conference on Education, Social Sciences and Humanities

DOI: https://doi.org/10.326/hum0205

\title{
Method Tracing Using Paint Tool Sai in Learning Arts to Improve 2 Dimensional Works Ability
}

\author{
Tjitjik Sriwardhani ${ }^{1}$, Purwatiningsih ${ }^{2}$ \\ 1,2Universitas Negeri Malang, Jawa Timur, Indonesia, \\ (*)凶 ciciksw@yahoo.ac.id
}

\begin{abstract}
In the implementation of teaching and learning art, sketch drawing or drawing shapes technique, is used as part of 2-dimensional work. This technique must be mastered to meet the target and learning objectives of teaching and learning art. However, the result of the technique mastery obtained varied, considering that the techniques to be mastered have different characteristics, and must be done manually. The development and role of science and technology is increasing in various sectors, including in the education. The use of tracing method using Paint Tool Sai application is interpreted as a way of drawing creatively-artistically as desired using simple techniques by processing images. The use of modified research and development, of Defining, Collecting Data, Designing, Developing, and Disseminating, is validated. The development of learning innovations in learning strategies through the use of tracing method using Paint Tool Sai is a complementary application that can be realized in the teaching and learning activities in the classroom. It can improve the ability to master the techniques and procedure of drawing on individual character, being more independent and creative, to develop sustainably to achieve the learning objectives optimally.
\end{abstract}

Keywords: tracing method, paint tol sai, $2 \mathrm{D}$

\section{Introduction}

To improve education quality, some attempts have actually been carried out by the government not only in the course of policies issued but also in the real practices. At the policy level, it can be seen in the education section of GBHN (Garis Besar Haluan Negara or State Policy Guidelines) which revised once in a five-year. And also the renewal of some Laws as related to Education like the renewal of National Education Law, the renewal of the Regional Government Law relating to Education, and the renewal of Government Regulations on Education. Education curriculum is also the side which is updated and improved in almost every 10 years. At the practical level, those policies are then socialized and have been carried out in the form of curriculum development, teacher capacity building training, or collaborating with education experts from higher education institutions, and between universities. 
Seeing the indicators, however, the quality of education has neither shown any significant improvement nor reached its full potential. Why? There are at least two important factors; (1) the policy and implementation of national education that still uses an educational production function approach that prioritizes input from the education process, and (2) the implementation of centralized national education depends on bureaucracy which causes uniformity in the administration of education ( Umaedi, 2000). Both factors make the national education process is less able to accommodate the needs and interests of students in keeping with the real

In an effort to improve the quality and to explain a more contextual education concern, the Department of Art and Design, especially the Fine Arts Study Program, has set the education autonomy strategies. One of them is in the development, presenting several compulsory subjects and work expertise according to specialization as an enrichment of expertise in the field of Fine Arts, including form drawings, sketch drawings, and interior design which were presented as 2dimensional work. This course provides learning experiences to students to be independent and creative in visualizing themselves through drawing shapes, sketches and or designs. Thus, the competencies which need to be achieved include (a) understanding form drawing theory, mainly the principle of lighting and the use of the color medium, (b) forming advanced skills using array color of media through the application of various techniques. Likewise, the competencies that will be achieved in drawing sketches are (a) understanding sketch theory related to the functions, techniques, and principles of drawing sketches, (b) forming skills in using techniques and procedures for transforming visual perceptions using sketch techniques. The above-mentioned competencies are compiled based on the 2013 Curriculum which rooted on the Indonesian National Qualifications Framework (Department Catalog 2017).

These techniques, practically speaking, must be mastered by students to meet their targets and learning objectives. But the mastery of the technique obtained is varied while the students are less motivated, considering the use of techniques that must be mastered have different characteristics and must be done conventionally with manual techniques. For this reason, it is necessary to think about the development of learning innovations through the use of technology and solutions that assist creation while at the same time increasing drawing skills as a 2-dimensional work. On the other hand in the present-day era, many young people are fonder of technology and learn to draw using digital techniques.

The development of science, technology, and art (Science and Technology) today brings various changes in human life. The role of Information and Communication Technology (ICT) is increasingly being felt in various sectors, including in the education sector. Being able to change the human mindset in solving problems, from being done manually can be replaced with the help of technology. Such progress can trigger an effort to change the technological system to be very important for human life (Jim Leggit, 2012).

Conversely, at the level of the implementation of learning in secondary schools, there is a presentation of art learning with basic competencies (or Kompetensi Dasar in Indonesian / KD) analyzing the media, techniques and work processes of art and making modified 2-dimensional works of art. From the core competencies of processing, reasoning and presenting in concrete and abstract realms related to the development of those that are studied independently, effectively and creatively and use them according to their rules. These techniques must be mastered to meet learning outcomes and objectives (Curriculum 2013).

Based on observations in the field, however, it can be identified that mastery of work techniques obtained an array of results. Students are less motivated because they feel they do not have talent, especially the techniques that must be mastered to work have different characteristics and must be done with manual techniques. While in the 2013 curriculum, all subjects must be integrated with information and communication technology. Teachers are required to be able to develop the ability to use technology in making representative learning media as a supporting medium in the learning 
process. The governess should realize the potential of technology as a source of learning for students (Chao, Parker, \& Howcort, 2011). In line with the aforementioned view, Glum (2015) revealed that generation $\mathrm{Z}$ is a generation born and raised with the internet, and has become a part and style of life. Conventional things are not very popular, and their lives require the intervention of technology and new ways of delivering them. Darmawan (2012: 89), correspondently, reveals that through the development of technology and communication, it is expected that studies of concepts and theories related to the problem of technology-based learning methodology in the art education environment are becoming more innovative.

The results of the case study conducted by Bartoon, et al. (2013) prove that applying technologybased learning can encourage students to reach understanding as well as to actively engage in creative work. Related to these problems, it is necessary to develop a learning innovation through the use of technology, and a solution that makes it easy to develop as a method that can improve the ability to draw sketches, draw shapes or design interior design, by means of 2-dimensional subject course.

Paint Tool SAI is one of the application choices in developing technology-based learning innovations for drawing sketches, drawing shapes or interior design, which is interpreted as a way of drawing according to the desired creative-artistic way by using simple techniques. This is an image processing software using computers with easy and lightweight memory (Wikipedia, 2018). It can also be used to design visualizations of works with the desired shape in several other subjects to complete the picture in the creation of 2-dimensional works.

The Tracing method itself is a copy method as one way of drawing on the Paint Tool SAI application from the selected image object using the Pen Tablet as hardware for hand drawing and inserting sketch images directly into the computer, such as drawing on paper. (Wikipedia, 2012).

The development of learning innovations in learning strategies with the tracing method in Paint Tool SAI software, which is a complementary application to improve students' work skills, is expected to have several things as following: (a) the aptitude of 2 Dimensions in drawing shapes or sketches can increase, especially in mastering techniques and the procedure of working, (b) the arrangement of 2-dimensional artworks with original and personal characteristics, in the embodiment of images or designs, and (c) the utilizing of 2-dimensional artworks that have personal and original characteristics.

By means of using complementary applications, on this very learning innovation development, it is expected that there will be an increase on the two-dimensional aptitude artistically, independently, creatively, develop continuously and learning objectives can be achieved optimally.

\section{Method}

The design of developing learning innovations using the tracing method in Paint Tool SAI application is intended to improve the ability of students to work in 2-Dimensional Arts presented in the odd semester 2018/2019 Art Education Study Program, Department of Art and Design, Universitas Negeri Malang. This is assisted by applying a procedural design to produce a 2 Dimensional product platform.

The development method employed using the Five-D model which is consists of Define, Data, Design, Develop, and Disseminate, with the stages:

Define, which identifies problems, is obtained when lectures are analyzed as needs. Data, which was obtained from the problem as a development background was analyzed to produce the concept of platform products. Furthermore, designing, developing instruments of validation and testing in Design. Next, Develop is done developing an initial platform that is feasible or not to is used, ending the deployment (dissemination) of products/platforms that have been developed. 
The subjects of this learning innovation development study are the students who take a 2dimensional course, the experts who master Paint Tool SAI application and also 2-Dimensional material experts who ace and understand drawing shapes and drawing sketches. In this study, the researcher carried out individual tests and small group tests.

The data sources needed for the very research were as follows, Art Education Study Program 2018 curriculum, text tracing book method on the Paint Tool SAI application, which was packed in Fine Art 2 Dimensions of student work, either those using applications or conventional manual techniques with color pencil shading. The instruments used were in the form of observation sheets, expert validation instruments, tracing method software expert uses the Sai Paint Tool application and 2 D work material experts, as well as product trial questionnaires, were given to 20 students.

\section{Results and Discussion}

Sukmadinata (2006: 171) describes that product development in education can be in the form of hardware or software. In accordance with that, the development of these learning innovations containing software category which was supported by hardware- in the form of 2 D works, using the conventional method of manual color pencil shading techniques, and the tracing method on Paint Tool SAI application with the form chosen or created by students. This step initiated with the stages of product/platform development, data analysis and revisions.

The concept of the development platform would include the selection of applications/software and formats, which match the characteristics of the material works as well as $2 \mathrm{D}$ in the form of tracing method software on Paint Tool SAI. It then presented in a brief explanation according to the discussion of the material and operation of Paint Tool SAI program. The data collection techniques used was quality and suitability; as well as the appropriateness of the application.

Data about the quality of this computer technology-based innovation learning media is in the form of descriptive data. Once the data is collected from experts, students, and the results of the trial, then the percentage is calculated by using the following formula.

$\mathrm{P}=\mathrm{f} / \mathrm{n} \times 100$

Legend:

$\mathrm{f}=$ The frequency that the percentage is looking for.

$\mathrm{N}=$ Number of Cases (number of frequencies/number of individuals).

$\mathrm{P}=$ Percentage Rate.

The data collected then reprocessed in the form of qualitative data which is the result of a descriptive form of existing quantitative data, and matched with the program eligibility criteria stated in the following table:

Table 1. criteria percentage

\begin{tabular}{cll}
\hline Criteria & Percentage & Qualification \\
\hline A & $80 \%-100 \%$ & Feasible \\
B & $60 \%-79 \%$ & Quite feasible \\
C & $50 \%-59 \%$ & Less feasible \\
D & $0 \%-49 \%$ & Not feasible \\
\hline Source: Arikunto 2007 & &
\end{tabular}

The data collection techniques used is the quality and feasibility of the application. The display of the application result is in simple form so that it may attract users and it is easier for users to operate the application. 
The data obtained then reprocessed in the form of qualitative data which is the result of descriptive forms of existing quantitative data and is matched with the program's eligibility criteria. Expert tests were intended solely as view or estimation to assess the feasibility of the basics of the concepts used and to see the feasibility of the product on a macro basis. In the validation test carried out by two people from media experts and one person from the material expert, with criteria for determining experts according to the field of study and understanding of the product/platform developed.

The results of the assessment of the quality of learning innovation media Paint Tool Sai software and material experts in terms of material aspects are amounted to $92 \%$ with a very good category, in terms of the learning aspect of $100 \%$ with very good categories, and from the evaluation aspect of $100 \%$ with very good categories.

Table 2. Results of the Paint Tool Sai Application Feasibility Assessed by Material Experts

\begin{tabular}{cc}
\hline Aspect & Percentage \\
\hline Material & $92 \%$ \\
Learning & $100 \%$ \\
Evaluation & $100 \%$ \\
\hline
\end{tabular}

Overall the quality of learning innovations developed was assessed by material experts $97 \%$ with very good categories. This is because the average percentage of each aspect has a percentage above $90 \%$ with the criteria very good or very decent. The material contained in the application is quite complete and the material is in accordance with basic competencies.

As for the results of the assessment of the quality of innovation learning with the tracing method using the Sai Paint Tool application in terms of the display aspect of $93.75 \%$ with a very feasible category, from the aspect of ease in the learning process it was $95.38 \%$ with very good categories, and reviewed from aspects of software engineering amounted to $92.18 \%$, with a very good category.

Overall the quality of the innovations developed in the learning was assessed by 2 application experts at $93.92 \%$ with very good categories.

Table 3. Results of the Paint Tool Sai Application Feasibility Assessed by Material Specialists

\begin{tabular}{lc}
\hline Aspect & Percentage \\
\hline Display & $93.75 \%$ \\
Learning & $95.83 \%$ \\
Application engineering & $92.18 \%$ \\
\hline
\end{tabular}

The results of the assessment of the quality of innovation developed in the $2 \mathrm{D}$ artwork learning by students in terms of the display aspect were $83.75 \%$ with very good categories, in terms of the ease of application of learning at $85.83 \%$ with very good categories, in terms of material aspects amounting to $82.18 \%$ with a very good category, in terms of the learning aspect of $93.11 \%$ with a very good category, and from the aspect of application engineering $93.67 \%$ with a very good category. Overall the quality of learning innovations in learning is tested on students who take the work subjects. 2 Dimensions of the Fine Arts Education Study Program are 91.40\% with very good categories.

Table 4. Results of the Sai Feasibility Paint Tool application by students

\begin{tabular}{lc}
\hline Aspect & Percentage \\
\hline Display & $83.75 \%$ \\
Ease of application & $85.83 \%$ \\
Materials & $82.18 \%$
\end{tabular}


$\begin{array}{ll}\text { Learning } & 93.11 \% \\ \text { Application engineering } & 93.67 \%\end{array}$

Based on the results of small group trials conducted on 20 students taking $2 \mathrm{D}$ work, the lowest percentage was found in the material aspects with good categories. Based on the overall data processing formula, the percentage was $87.70 \%$. If it is adjusted to the program eligibility criteria table, then it is classified as a feasible qualification. If it is adjusted to the program eligibility criteria table, then it is classified as a valid qualification, which means it is worthy of use and worthy of dissemination.

The results of the research on the development of learning innovations in learning 2-dimensional artwork have been carried out and have a very good category by the expert team. This is because the application that is made can run properly and there are no crashes/errors when the application is used. The content contained in the application is quite complete, the interface is attractive and the application is easy to use. So that with innovative learning in technology-based learning can increase the ability to work to the maximum. This becomes an advantage of course compared to the learning that has been done conventionally with manual techniques in learning that are carried out in 2dimensional fine arts courses.

The selection of the tracing method application format using the Paint Tool SAI is based on the tendency to use technology developed in learning innovation among nowadays students. This is supported by the existence of a learning system that uses software with an independent and creative system. Working on art that was originally done in a conventional way with manual techniques becomes specific learning required to master techniques and work procedures developed in learning innovation because learners can access learning materials, directions, and applications related to learning, anywhere and anytime. This will increase attention to learning materials, make learning interesting, and can encourage students' motivation in creating $2 \mathrm{D}$ art.

For the world of education, the widespread use of software tools is an aptitude and solution for the development of learning innovations with new systems that can meet the needs of the global demands for the world of education. The utilization of technology in work has been used as a learning media. In the future, similar applications will not only become a mere learning media but can also be a learning method. This research also opens wide opportunities for other researchers to develop in other various fields.

\section{Conclusion}

Taking a look at the results of the study, it can be concluded that the development of innovative learning through the tracing method in Paint Tool SAI software on learning work 2 D has the advantage after being tested by experts and students. The data validation shows that the product/platform developed is very feasible to be implemented in class learning, especially in 2D product classroom, since the display aspect has a value of $93.75 \%$, writing aspects $95.83 \%$ and software engineering aspects $92.18 \%$. Likewise, with the results of trials to students, the average value for the application developer has shown a very good category to be able to develop $2 \mathrm{D}$ work skills.

The concept of the platform with the tracing method in the Paint Tool SAI application is chosen as development as it is not only innovative, interesting, effective, and efficient, but also has a great opportunity to be developed into a learning method in high school. Its use in learning can change the way students perceive the benefits and functions of $2 \mathrm{D}$ artwork, increase students' interest in learning to work art in learning technology-based Arts by touching aspects and interests of students. Taken as a whole, this method is able to provide appropriate situations and learning methods for student characteristics.

\section{Acknowledgment}


Our gratitude goes to LP3 UM - IDB (Islamic Development Bank) who helped to fund this research activity in the Inobel program conducted in the year of 2018. Our thanks also go to the students participated in the class of $2 \mathrm{D}$ Works.

\section{References}

Chao, Parker, \& Howcort, (2011). bartoon,darmawan

Barnadib, I. (1988). Ke Arah Perspektif Baru Pendidikan. Jakarta: Ditjen Dikti-PPLPTK

Barton, G. \& Ryan,M. (2013). Multimodal approaches to reflective teaching and assessment inhigher education. Higher Education Research \& Development, 2014 Vol. 33, No. 3, 409-424, http://dx.doi.org/10.1080/07294360.2013.841650

Chao, J.T., Parker, K.R \& Fontana, A. (2011). Developing an Interactive Social Media Based Learning Environment. Social Media Learning Environment. 8:324-334

Darmawan, Deni. (2012). Inovasi Pendidikan Pendekatan Paktik Teknologi Multimedia dan Pembelajaran Online. Bandung: PT Remaja Rosdakarya.

Glum, J. (2015). Marketing to Generation Z: Millenials move aside as brand shift focus to under 18 costumers International Bisniss Time.

Jim Leggit, (2012). Teknik Menggambar Cepat. Bandung : CV. Maulana

Katalog Jurusan Seni Desain. 2017. Deskripsi Matakuliah Prodi Pendidikan Seni Rupa. Malang: Fakultas Sastra Universitas Negeri Malang

Marcelino, M; Gomes, A; Dimitrov, N; Mendes, A. (2014). Using a computer-based interactive system for the development of basic algorithmic and programming skills. International Conference on Computer Systems and Technologies -.

Newby, T.J., Stepich, D.A., Lehman, J.D., \& Russell, J.D. (2000). Instructional Technology for Teaching and Learning. Design Instruction, Integrating Computers, and Using Media. Second edition. Prentice Hall, New Jersey.

Sukmadinata, N.S. (2006). Metode Penelitian Pendidikan. Bandung: PT Remaja Rosdakarya

Umeidi. (2000). Pembelajaran Berbasis Lingkungan. Diunduh dari http://irwansahaja.blogspot.co.id/2014/07/pembelajaran-berbasis-lingkungan.html

Universitas Negeri Malang. 2010. Buku Pedoman Penulisan Karya Ilmiah, Skripsi, Tesis, Dosertasi, Artikel, Makalah, Laporan Penelitian. Malang: Penerbit UM

Universitas Negeri Malang (2006). Peraturan Pemerintah No. 14 Tahun 2005 tentang Standar Nasional Pendidikan. Depdiknas.go.id. (accessed 9 Sep 2016).Online

MODEL PEMBELAJARAN NILAI DAN KARAKTER... (PDF Download Available). Available from: https://www.researchgate.net/publication/307686829MODEL PEMBELAJARAN NILAI DAN KARAKTER BERBASIS NILAI-NILAI KEHIDUPAN DI SEKOLAH DASAR [accessed May 20 2018].

Wikipedia.(2018). Paint Tool SAi (online) (http;//en.m.wikipedia.org.diakses 14 mei 2018.

Wikipedia. (2012). Sketsa (gambar). (online). (https://id.m.wikipedia.org/wiki/istimewa: History/Sketsa_(gambar). Diakses 15 Mei 2018. 